\title{
外部形態測定值によるヒヨドリの雌雄判別
}

\author{
中村和 雄 ${ }^{*}$ ・佐藤文男 ${ }^{* *}$ ・杉森文夫** \\ 今 村知子**
}

\section{Sex Discrimination Based on External Morphological Measurements in Brown-eared Bulbul Hypsipetes amaurotis}

\author{
Kazuo Nakamura*, Fumio Sato**, Fumio Sugimori** \\ and Tomoko Imamura**
}

\begin{abstract}
Ten external morphological variables were obtained from four different kinds of specimens of Brown-eared Bulbul Hypsipetes amaurotis which differed both in capture site and in condition of storage. Almost all the variables were larger in males than in females, showing a pronounced sexual size dimorphism. The specimens kept as study skins differed in both means and variances of almost all of the variables from fresh or frozen specimens.

A discriminant function analysis was done for the specimens which had been collected from the same site in the same season. As a result, a discriminant function incorporating the lengths of tarsus, bill from nostril, total length, wing span, total head and width of bill at nostril could discriminate sex correctly at the probability of wrong discrimination of 0.021 . Another two discriminant functions for more general situations were derived from an analysis of specimens collected from various sites, incorporating lengths of tail, tarsus, bill from nostril, wing span and total head, or the lengths of natural wing, tail, tarsus, exposed culmen and total head. We can use these functions for discriminating sex with an accuracy of $95 \%$.

These functions correctly classified sex of only $74 \%$ of study skins, showing that they could not be reliably applied to these specimens.
\end{abstract}

\section{は じめに}

ヒヨドリHypsipetes amaurotis は, 現在では全国で留鳥として生息する。しかし，北海道， 東北地方などで繁殖した個体群の多くのものは, 秋から冬にかけて本州の西南部から四国, 九 州方面へ移動するといわれているものの，その実態は汪とんど分かっていない(吉井 1979)。一 方，ヒヨドリは冬期に作付されるキャベッやハクサイ，ホウレンソウなどの野菜の葉を食害し， 大きな被害を与えており, その被害の発生はヒョドリ個体群の移動と深く係っていることが推 察されるが (中村ら 1983)，その実態はやはり不明である。

ヒヨドリの移動の実態を解析するためには, 全国各地で採集された標本を比較して地域個体 群について解析することが考えられるが (James et al. 1984), その際, 捕獲された標本の雌雄

Received 17 July 1989, accepted 21 August 1989

* Bird Control Laboratory, National Agriculture Research Center, Kannondai, Tsukuba, Ibaraki, 305 Japan.

** Yamashina Institute for Ornithology, Konoyama, Abiko, Chiba, 270-11 Japan 
を判定する必要がある。しかし，ヒヨドリでは雌雄間で異なる羽色などの特徵は知られていな いため (清棲 1978), 捕獲した個体の雌雄を判定する方法が確立される必要がある。村田 (1986) は, 山口県宇部市で採集された個体の翼長を測定した結果, ある值を境にして雌雄を判別でき ることを見いだした。しかし，雌雄の翼長の頻度分布は互いに重なっており，この判別は絶対 的なるのではない。

そこで, 複数の形態部位の計測值を基に判別分析を行って，できる限り精度が高く，一般的 な判別式を得ようとした。判別分析は, 多変量解析の一つで, 2 種以上の異なったグループを 判別するのに広く用いられている方法で, 鳥類の雌雄や幼・成鳥の判別のためには, Bald Eagle (Bortolotti 1984, Garcelon et al. 1985), Red-legged Partridge (Pepin 1985), タンチョウ (村田ら 1988), Tundra Swan (Miller et al. 1988), Great Crested Grebes (Piersma 1988) 等で 行われている。

なお，著者らはここで用いた標本を基に，頭骨の骨化の進行状況から年齢の推定を試み，ま た計測値の主成分分析から地域個体群の形態上の変異について解析中であり，これらの結果は 別途発表する予定である。

この分析に用いた標本の収集と捕獲には，以下の方々にお世話になった。神奈川県園芸試験 場三浦分場 大林延夫氏, 神奈川県横須賀市 西脇一夫氏, 森林総合研究所鳥獣管理研究室 平川浩文氏, 愛知県農業総合試験場作物研究所 種田芳基氏, 奈良県農林部 杉浦哲也氏, 奈 良県林業試験場 柴田㕡式氏, 果樹試験場興津支場 是永龍二氏, 静岡県柑橘試験場 古橋嘉 一氏, 東京大学農学部森林動物学研究室 宮下直氏, 食品総合研究所 小滝豊美氏, 山階鳥類 研究所資料室, 池谷犬・猫・鳥の病院 池谷奉文氏とそのスタッフの皆様, 千葉県行徳野鳥観 察舎 蓮尾嘉彪氏・純子氏, 柏動物病院 荣原秀樹氏, 日本大学農獣医学部 野谷靖浩氏, 鴨 川市 前原一統氏。また, 農業研究センター鳥害研究室 松岡 茂氏には, ヒヨドリの捕獲に お世話になったほか，本論文の取りまとめに当たり，貴重な意見をいただいた。農業環境技術 研究所植生管理科 塩見正衛氏からは, 本論文の特に統計学的な取扱いについて適切な助言を いただいた。これらの方々に深く感謝する。

\section{材 料と方 法}

\section{1. 標本}

この分析に用いた標本は, Table 1 の通りで, 雌 235 羽, 雄 159 羽, 計 394 羽である。この

らち, $\mathrm{A}$ 扣よび $\mathrm{C}$ は, 標本収集直後に計測を行った。Bは, 各地から収集されたのち, ディー プフリーザー内で冷凍保存されていたものである。これらは，主として有害鳥獣駆除のために 銃で捕獲されたものと，学術研究のために果物を慨としたトラップで捕獲されたものである。

また, D は, 山階鳥類研究所標本室に保存されていたヒヨドリのうち, 北海道, 本州および 九州で採集されたものである。

\section{2. 形態測定}

標本 A, B, C について (Table 1), 自然翼長 Natural wing, 尾長 Tail, 跗蹠長 Tarsus, 露 出嘴峰長 Exposed culmen, 鼻孔前端から嘴先端までの長さ (鼻孔前端長) Bill from nostril, 全 長 Total length, 翼開長 Wing span, 全頭長 Total head, 鼻孔前端の嘴高 Height of bill at nostril，鼻孔前端の嘴幅 Width of bill at nostril，体重 Body weight を測定した。ただし，破 
損等により測定できなかった測定部位を持つ標本が多くあった。測定には，著者のうち佐藤一 人が当たり，測定者の違いによる誤差が生じないようにした。各部位の測定にはノギスを用い て，1/10 mm まで読み取り，体重は電子天科を用いて，1/10 g まで読及取った。標本は計測 後, 解剖して精巣あるいは卵巣の存在に基づいて雌雄を判定した。

標本 D については, 跗蹠長その他の部位の正確な測定が困難であったため, 自然翼長, 尾 長, 露出嘴峰長, 鼻孔前端長, 嘴高, 嘴幅の 6 部位だけを測定した。

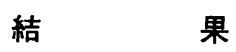

\section{1. 計測値の雌雄間と標本間の比較}

ここで用いた標本 (Table 1 の標本 A〜D) ごとに得られた計測值を，雌雄に分けてそれぞれ の平均值と分散とを求めた (Table 2)。その結果を，まず，各標本ごとに雌雄間で比較してみる と, 標本 $\mathrm{A} \sim \mathrm{B}$ ではすべての変数 (計測值)で有意差が認められ, 雄の值が踓の值よりも常に 大きかった。標本 Cでは, 跗蹠長, 鼻孔前端長, 嘴幅以外の变数で有意差が認められた。それ に対して, 標本 D では, 自然翼長と尾長で有意差が認められたが，それ以外の变数では有意差 は認められなかった。

Table 1. Specimens used for the discriminant function analysis

\begin{tabular}{|c|c|c|c|c|c|c|c|}
\hline \multirow{2}{*}{$\begin{array}{l}\text { Spec- } \\
\text { imen }\end{array}$} & \multicolumn{3}{|c|}{ Capture } & \multicolumn{4}{|c|}{ No. of individuals } \\
\hline & Site & Year & Month & ㅇ & $\hat{s}$ & $\mathrm{U}^{*}$ & Total \\
\hline \multirow[t]{4}{*}{ A. } & Miura, Kanagawa Pref. & 1988 & 1 & 56 & 26 & 0 & 82 \\
\hline & & 1988 & 2 & 52 & 8 & 0 & 60 \\
\hline & & 1988 & 3 & 12 & 8 & 0 & 20 \\
\hline & Total & & & 120 & 42 & 0 & 162 \\
\hline \multirow[t]{8}{*}{ B. } & Tsukuba, Ibaraki Pref. & $1983 \sim 88$ & $10 \sim 2$ & 14 & 20 & 5 & 39 \\
\hline & Miura, Kanagawa Pref. & 1984 & 2 & 28 & 11 & 2 & 41 \\
\hline & Shimizu, Shizuoka Pref. & 1985 & $3 \sim 4$ & 1 & 4 & 0 & 5 \\
\hline & Toyohashi, Aichi Pref. & 1984 & $1 \sim 2$ & 11 & 5 & 4 & 20 \\
\hline & Kooriyama, Nara Pref. & 1986 & 3 & 17 & 6 & 0 & 23 \\
\hline & Kashihara, Nara Pref. & 1984 & $3 \sim 4$ & 5 & 18 & 1 & 24 \\
\hline & Arita, Wakayama Pref. & 1986 & 1 & 1 & 2 & 0 & 3 \\
\hline & Total & & & 77 & 66 & 12 & 155 \\
\hline \multirow[t]{3}{*}{ C. } & Miura, Kanagawa Pref. & 1988 & $9 \sim 10$ & 5 & 4 & 0 & 9 \\
\hline & Tokyo and its outskirts & $1985 \sim 88$ & $12 \sim 8$ & 5 & 3 & 0 & 8 \\
\hline & Total & & & 10 & 7 & 0 & 17 \\
\hline \multirow[t]{4}{*}{ D. } & Hokkaido & $1921 \sim 51$ & $1 \sim 12$ & 4 & 12 & 1 & 17 \\
\hline & Kanto & $1883 \sim 1985$ & $7 \sim 4$ & 12 & 21 & 2 & 35 \\
\hline & Kyuusyuu and others & $1891 \sim 1971$ & $10 \sim 4$ & 12 & 11 & 0 & 23 \\
\hline & Total & & & 28 & 44 & 3 & 75 \\
\hline
\end{tabular}

* U: Unidentified.

Specimen $A$ and $C$ were measured just after the capture. Specimen $B$ had been stored in a freezer. Specimen D is study skins kept in Yamashina Institute for Ornithology. 


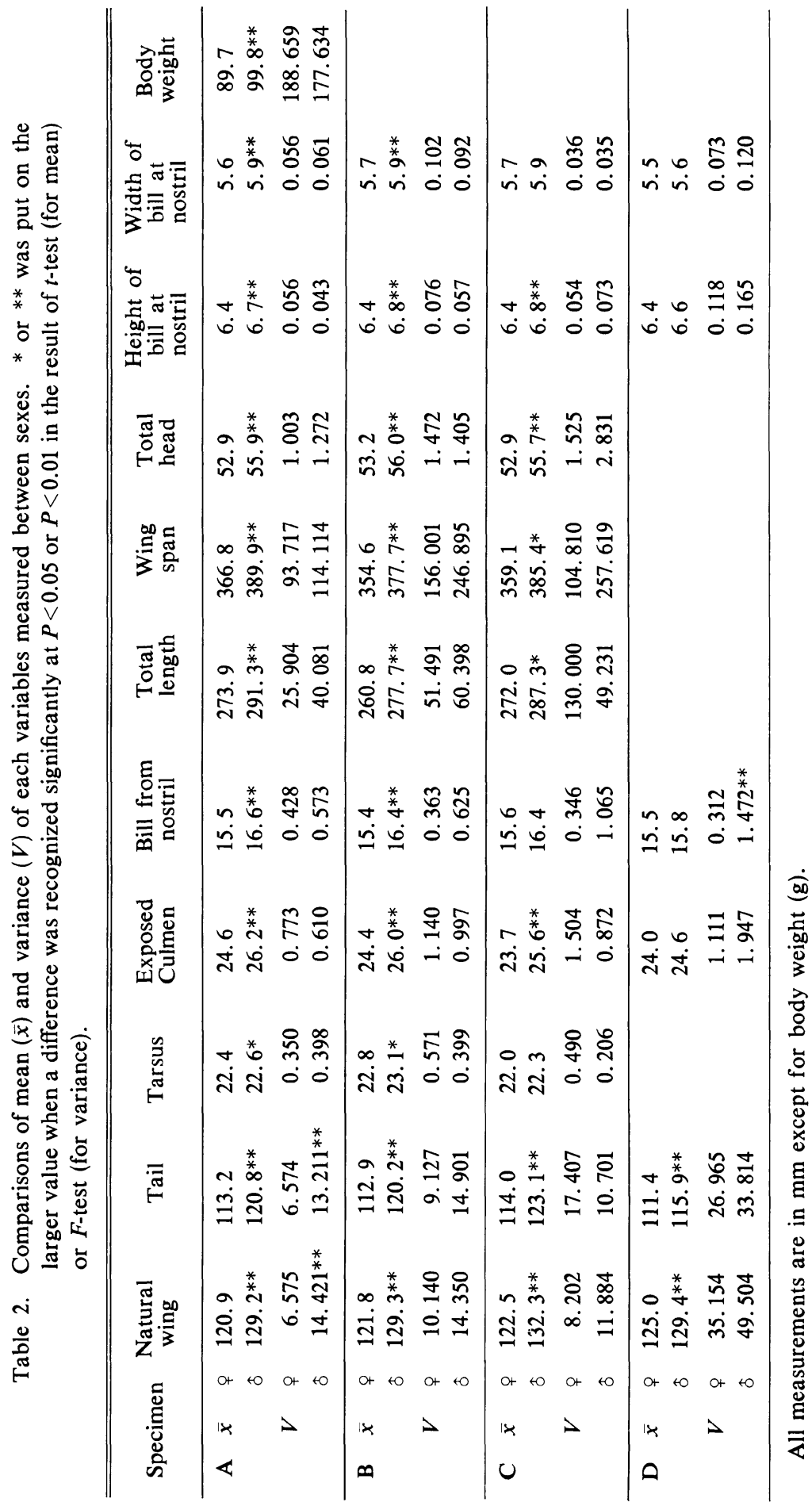


一方, 分散は二, 三の場合で雌雄間で有意差が認められた注かは，大部分の場合で，有意差 が認められなかった。

次に, 各標本間の採集地あるいは採集時期の異なるグループ (Table 1 参照) 間で, 雌雄それ ぞれの変数の平均值および分散を比較したところ, 両者ともほとんどの場合で有意差は認めら れなかった。

続いて，自然翼長について同様な比較を標本を異にするグループ間あるいは標本間で行った (Table 3)。まず，同一の採集場所 (神奈川県三浦半島) で採集された雄では，採集時期あるいは 標本の保存状態の違いによっては, 平均值および分散には有意差が認められなかった。雌では, 標本 A と B 間で $5 \%$ 水準で有意差が認められた。標本 A と乾燥標本である標本 D の間に は, 雄の平均值では有意差が認められなかったが, 雌の平均值および雌雄の分散とも $1 \%$ 水準 で有意差が認められた。

次に, 全長および翼開長を, 測定された標本 A, B, C 間で比較してみると (Table 4), 標本 $\mathrm{A}$ と $\mathrm{B}$, および標本 $\mathrm{B}$ と C との間で有意差が認められた場合が多く, 標本 $\mathrm{B}$ のこれらの值 は, 他の標本のものよりも小さかった。しかし, その他の变数では, 標本 $\mathrm{A}, \mathrm{C}$ と標本 $\mathrm{B}$ との 間には有意差は認められなかった。

以上の結果から，長期間冷凍保存されていた標本 B は，その間に变形したと思われる全長お よび翼開長を除くと，標本 $\mathrm{A} ， \mathrm{C}$ と同じ母集団からの抽出標本であると判定できょら。それに 対して, 乾燥標本 D は他のものとは異なったもので，両者を同一に扱らことはできないといえ る。

Table 3. Comparison of mean $(\bar{x})$ and variance $(V)$ in the length of natural wing among Specimen $\mathbf{A}$ and other specimens.

\begin{tabular}{|c|c|c|c|c|c|c|c|}
\hline & & $\begin{array}{c}\text { Miura in } \\
\text { Specimen B }\end{array}$ & $\underset{\text { (whole) }}{\text { Specimen }}$ & $\begin{array}{c}\text { Miura in } \\
\text { Specimen } C\end{array}$ & $\begin{array}{c}\text { Kanto in } \\
\text { Specimen D }\end{array}$ & $\begin{array}{r}\text { Hokkaido } \\
\text { Specimen D }\end{array}$ & $\begin{array}{l}\text { Specimen } \\
\text { (whole) }\end{array}$ \\
\hline \multirow[t]{2}{*}{$\bar{x}$} & q & $\mathbf{N}$ & $*$ & $\mathbf{N}$ & $*$ & $* *$ & $* *$ \\
\hline & $\delta$ & $\mathbf{N}$ & $\mathbf{N}$ & $\mathbf{N}$ & $\mathbf{N}$ & $*$ & $\mathbf{N}$ \\
\hline \multirow[t]{2}{*}{$V$} & 우 & * & $*$ & $\mathbf{N}$ & $* *$ & $* *$ & $* *$ \\
\hline & $\hat{\delta}$ & $\mathbf{N}$ & $\mathbf{N}$ & $\mathbf{N}$ & $* *$ & $* *$ & $* *$ \\
\hline
\end{tabular}

$*$ and ** are significant at $P<0.05$ and $P<0.01$, respectively. $\mathrm{N}$ is not significant.

Table 4. Comparison of mean $(\bar{x})$ and variance $(V)$ in total length and wing span among specimens.

\begin{tabular}{|c|c|c|c|c|c|c|c|}
\hline & & \multicolumn{3}{|c|}{ Total length } & \multicolumn{3}{|c|}{ Wing span } \\
\hline & & $\mathbf{A}: \mathbf{B}$ & $A: C$ & B : C & $\mathbf{A}: \mathbf{B}$ & $A: C$ & $B: C$ \\
\hline \multirow[t]{2}{*}{$\overline{\bar{x}}$} & 우 & $* *$ & $\mathbf{N}$ & $* *$ & $* *$ & * & $\mathbf{N}$ \\
\hline & $\hat{\delta}$ & $* *$ & $\mathbf{N}$ & $* *$ & $* *$ & $\mathbf{N}$ & $\mathbf{N}$ \\
\hline \multirow[t]{2}{*}{$V$} & ㅇ & * & $* *$ & $\mathbf{N}$ & $\mathbf{N}$ & $\mathbf{N}$ & $\mathbf{N}$ \\
\hline & $\hat{\delta}$ & $\mathbf{N}$ & $\mathbf{N}$ & $N$ & $*$ & $\mathbf{N}$ & $\mathbf{N}$ \\
\hline
\end{tabular}

* and ** are significant at $P<0.05$ and $P<0.01$, respectively. $\mathrm{N}$ is not significant. A, B and $\mathrm{C}$ means Specimens $\mathrm{A}, \mathrm{B}$ and $\mathrm{C}$, respectively. 


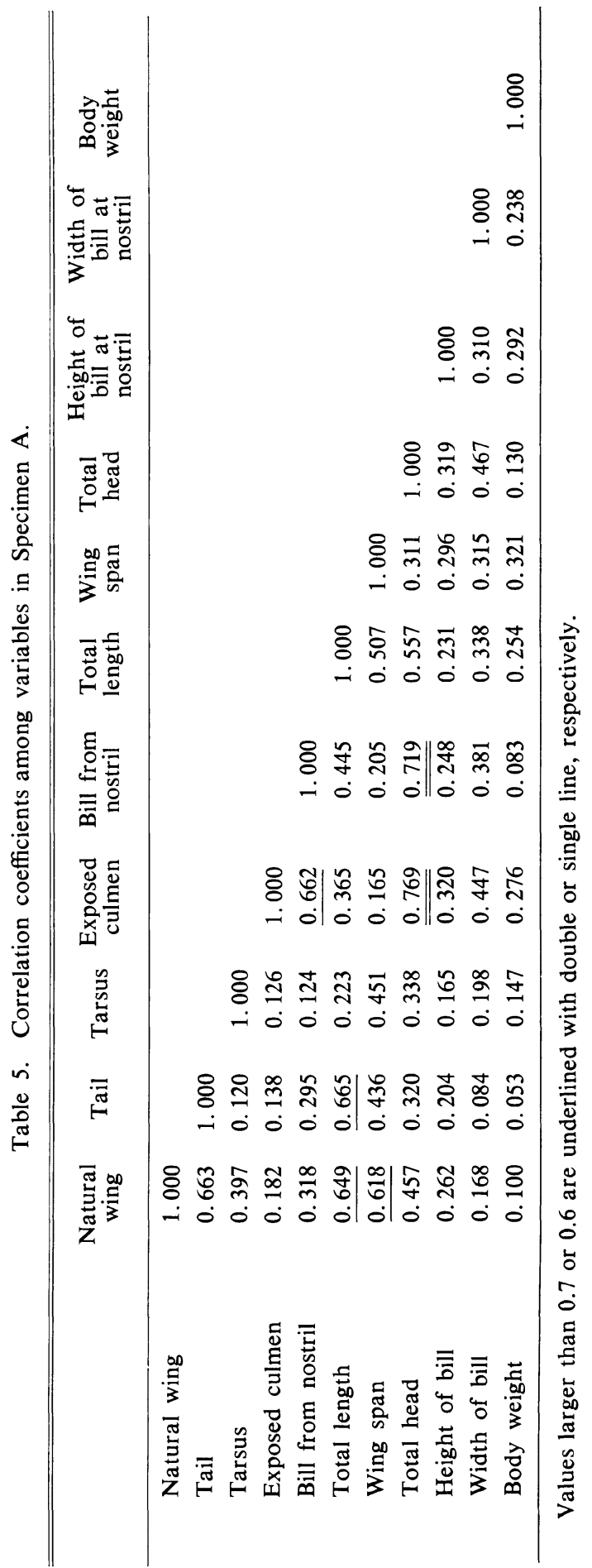




\section{2. 雌雄判別に有効な変数の検討}

初めに，判別式に組み込むべき変数を検討するために，同一シーズンに同一場所で採集され た標本 A を用いて, 判別分析を行った。まず, 測定した全变数 (11 变数) 間の相関行列を得 た (Table 5)。標本数は, 測定できなかった部位を持つ標本を除いたため, 雌 96 , 雄 38 , 合計 134 羽であった。

この表から, 自然翼長, 尾長, 全長, 翼開長の間には, お互いに高い相関が見られた（相関係

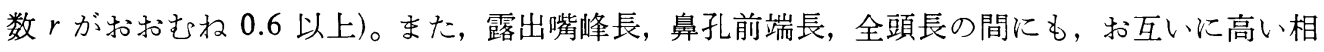
関が得られた。後者の変数間での相関は, 当然予想されることである。

体重は, 他の変数間との間で, いずれも高い相関は認められなかった。これは, 採集日間で 体重が大きく異なったためで, 体重の個体間の変異が季節変動によって覆い隠されてしまった ためである。この結果は, 以下の判別分析において, 体重はほとんど効いていないことを意味 する。

まず,ここで得られた 11 変数を使って判別分析を行った。その結果, 誤判別率 0.020 で, 雌雄を判別することができた (Table 7)。次に, この 11 変数のらち雌雄の判別に有意に効いて いる变数を選択するため, 変数増加法によって誤判別率を最小にする变数を選択していったと ころ, 全長, 全頭長, 鼻孔前端長, 跗蹠長, 翼開長, 嘴幅の 6 变数が選択され, このときの誤 判別率は 0.021 であった (Table 6,7)。また，判別関数として，

$$
d=219.441+2.549 x_{3}+2.323 x_{5}-0.338 x_{8}-0.164 x_{i}-3.387 x_{8}+4.549 x_{10}
$$

が得られた。ここで, $x_{3}$ : 跗蹠長, $x_{5}$ : 鼻孔前端長, $x_{8}$ : 全長, $x_{7}$ : 翼開長, $x_{8}$ : 全頭長, $x_{10}$ : 嘴

Table 6. Selection of variables for discriminating sex by step-wise method in Specimen A.

\begin{tabular}{clc}
\hline \hline Step & \multicolumn{1}{c}{ Variables } & $\begin{array}{c}\text { Probability of wrong } \\
\text { discrimination }\end{array}$ \\
\hline 1 & Total length & 0.051 \\
2 & Total head & 0.039 \\
3 & Bill from nostril & 0.033 \\
4 & Tarsus & 0.030 \\
5 & Wing span & 0.027 \\
6 & Width of bill at nostril & 0.021 \\
\hline
\end{tabular}

Table 7. Summary of discriminant function analysis in Specimen A.

\begin{tabular}{lccc}
\hline \hline Variables used & $\begin{array}{c}\text { No. of } \\
\text { variables }\end{array}$ & $\begin{array}{c}\text { Discriminant } \\
\text { efficiency }\end{array}$ & $\begin{array}{c}\text { Probability of } \\
\text { wrong discrimination }\end{array}$ \\
\hline All variables & 11 & 16.733 & 0.020 \\
Selected variables* & 6 & 16.446 & 0.021 \\
Basic variables** & 4 & 10.862 & 0.050 \\
Natural wing & 1 & 7.619 & 0.084 \\
\hline
\end{tabular}

* Variables selected by the step-wise method (Table 6).

** Lengths of natural wing, tail, tarsus and exposed culmen.

Number of specimens used are 96 for females and 38 for males. 
幅 (単位は $\mathrm{mm}$ ) で, $d>0$ のとき雌， $d<0$ のとき雄と判定される。

したがって,この式を用いれば, 11 变数を用いたときとほぼ同じ判別効率でヒヨドリの雌雄 判別を行らことができる。

次に, 比較のために同じ標本を用いて, 自然翼長, 尾長, 跗蹠長, 露出嘴峰長の 4 変数 (れれ をここでは, 基本計測部位と呼ぶ)を用いた場合と, 自然翼長のみの場合について, 判別分析を 行った。その結果は, 基本計測部位のみでは, 誤判別率は 0.050 に上昇し, さらに自然翼長の みでは 0.084 に上昇した (Table 7)。

変数選択をさせた 6 変数による判別関数を, 分析に用いた標本に適用して雌雄を判別させた ところ, 誤判別率は雌では 0.011 , 雄では 0.086 , 全体では 0.030 であった。

\section{3. 一般的な判別関数の作成}

前節の検討は，同一シーズンに同一場所で採集された標本について行ったものであるから， そこで得られた判別関数が他の場所で採集されたヒヨドリの標本にもそのまま当てはまるかど らかは, 分からない。そこで, より一般的な判別関数を得るために, 先に行った平均值および 分散の比較から同質の標本と考えられる標本 $\mathrm{A} \sim \mathrm{C}$ にいて，判別分析を行った。

まず，計測した 10 部位（前節の分析で含めた体重を除く）を用いたときの誤判別率は 0.041 であった (Table 8)。次に, 変数増加法で变数を選択したところ, 全頭長, 尾長, 鼻孔前端長, 翼開長, 跗蹠長の 5 変数が選択され，そのときの䛊判別率は 0.043 であった。これを前節の結 果 (Table 6) と比較すると, 全長の代わりに尾長が選択され，嘴幅が除かれた。变数の平均值 と分散を標本間で比較した結果 (Table 4), 標本 B の全長および翼開長は，標本 A，Cのそれよ りも有意に小さかったが，そのため全長は雌雄の判別のための変数としては有効でなかったも のと考えられる。

これらの変数の代替として, 自然翼長, 尾長, 跗蹠長, 露出嘴峰長の基本部位に全頭長を加

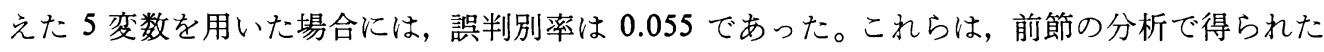
結果 (Table 7) よりも劣るが，捕獲した個体の雌雄を判別するためには許容できる範囲と考古 られる。

Table 8. Summary of discriminant function analysis in Specimen $\mathbf{A} \sim \mathrm{C}$.

\begin{tabular}{|c|c|c|c|c|}
\hline & Case 1 & Case 2 & Case 3 & Case 4 \\
\hline $\begin{array}{l}\text { No. of variables used. } \\
\text { Probability of }\end{array}$ & 10 & 5 & 5 & 6 \\
\hline $\begin{array}{l}\text { wrong discrimination } \\
\text { Actual ratio of }\end{array}$ & 0.041 & 0.043 & 0.055 & 0.067 \\
\hline wrong discrimination* & 0.008 & 0.000 & 0.017 & 0.017 \\
\hline$\hat{o}$ & 0.069 & 0.065 & 0.065 & 0.086 \\
\hline Total & 0.028 & 0.022 & 0.034 & 0.039 \\
\hline
\end{tabular}

* Result of the discrimination of sex in original specimens used for each analysis.

Variables used are: Case $1 \cdots$ All variables measured.

Case $2 \cdots$ Lengths of tail, tarsus, bill from nostril, wing span, and total head.

Case 3 . Lengths of natural wing, tail, tarsus, exposed culmen and total head.

Case $4 \cdot$ Lengths of natural wing, tail, exposed culmen, bill from nostril, height of bill and width of bill at nostril.

Number of specimens used are 120 for females and 58 for males. 
得られた判別関数は,

1）選択させた变数によるもの：

$$
\begin{aligned}
d= & 192.488-0.465 x_{2}+0.886 x_{3} \\
& +2.679 x_{5}-0.076 x_{7}-3.168 x_{8} .
\end{aligned}
$$

2) その代替:

$$
\begin{aligned}
d= & 164.183-0.224 x_{1}-0.394 x_{2} \\
& +0.383 x_{3}-0.085 x_{4}-1.856 x_{8} .
\end{aligned}
$$

Table 9. Results of sex discrimination in Specimen $\mathrm{D}$ based on the discriminant function obtained in the Case 4 in Table 8.

\begin{tabular}{cccc}
\hline \hline Sex & $\begin{array}{c}\text { No. of } \\
\text { specimens }\end{array}$ & $\begin{array}{c}\text { No. of wrong } \\
\text { discrimination }\end{array}$ & Ratio \\
\hline+ & 19 & 5 & 0.263 \\
$\delta$ & 35 & 9 & 0.257 \\
Total & 54 & 14 & 0.259 \\
\hline
\end{tabular}

ここで, $x_{1}$ : 自然翼長, $x_{2}$ : 尾長, $x_{3}$ : 跗蹠長, $x_{4}$ : 露出嘴峰長, $x_{5}$ : 鼻孔前端長, $x_{7}$ : 翼開長, $x_{8}$ : 全頭長 (単位は $\mathrm{mm}$ ) で, $d>0$ のとき雌, $d<0$ のとき雄之判定される。

次に, これらの式を，分析に用いた標本に適用したときの誤判別率を求めたところ (Table 8), いずれも雌の值が雄よりも低く，雌の方がより精度の高い判別が行われることを示した。

\section{4. 乾燥標本への適用}

先に検討した標本ごとの平均値と分散の比較 (Table 3) からは，捕獲直後に測定したものお よび冷凍後解凍したもの（標本 $\mathrm{A} \sim \mathrm{C}$ ） と乾燥標本として長期間保存されていたもの（標本 D) とは, 異質の母集団からの抽出標本であると結論された。このことから, 前節で得られた判別 関数は，乾燥標本には適用しにくいことが予想されるが，あえて適用した場合の判別精度はど のくらいであろらか？このことを知るため, 標本 D の測定結果を用いて，以下の検討を行 った。

標本 D では，跗蹠長のほか 3 部位の測定ができなかったため，前節で得られた二つの判別 関数 (式 (2),(3)) はいずれも適用することができない。そこで, 標本 A， B，Cを合わせたデー タについて，標本 D で測定された 6 変数を用いた判別分析を行った。その結果 (Table 8 の Case 4), 先に得られたものよりも多少高い誤判別率をもった判別関数が得られた。

次に, この判別関数に標本 D の測定値を当てはめて, 雌雄を判定し, 実際の雌雄 (標本のラ ベルに記載されていたもの）と比較した（Table 9)。その結果は，全体での誤判別率が， 0.259 で, 分析の結果から予想されるもの (0.067) よりはるかに高かった。この場合は, 新しい標本 に判別関数を適用したわけであるから，判別分析に用いた標本の誤判別率より高くなることは 当然であるが，得られた值はその場合に予想されるよりも高い值である。また，雌雄それぞれ の誤判別率は, 雌雄間でほとんど差がなかった。誤判別率と標本の採集地あるいは採集された 年との間には，特別な関係はみられなかった。

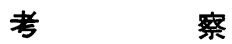

ヒヨドリの形態測定値の 平均值の比較では (Table 2)，標本 A〜C ではここで測定したほと んどの部位が雄の方が雌よりも有意に長く，体のサイズにおける明瞭な性的二型が示された。 ヒヨドリの体のサイズは雄の方が踓よりも大きいことは, 山階 (1933), 清棲 (1978) が示してい る計測值や，村田 (1986) の翼長の測定結果から示唆されていたことである。しかし，自然翼長 
だけを用いたときの誤判別率は，同一シーズンに同一場所で採集された標本を用いた場合でも 0.084 であったから (Table 6), 翼長だけを用いた村田（1986）による方法では，判別精度はそ れほど高くないといわなければならない。

この標本では, 単一の変数だけによる判別では全長を用いた場合の誤判別率 $(0.051)$ が最も 低く (Table 6), 判別のための変数には翼長よりはすぐれていることを示している。これに,さ らに別の变数を加えていくと誤判別率は低下していったから，単一の变数によるよりは複数個 の変数を用いた多変量解析の効果が大きいことが分かる。しかし，6 変数を用いたときの誤判 別率は，ここで測定した全变数である 11 变数を用いたときとほとんど同じ值であったから， このデータでは 6 変数以上を取り込んでも雌雄の判別にはほとんど効果がないことを示して いる。さらに, Table 6 の結果をみると, 実用的なとヨドリの雌雄判別のためには, 2 個ない し 3 個の変数を用いることで十分であるといえる。

一方，全国各地から採集された標本も加えて検討した結果では，基本計測部位 (自然翼長，尾 長, 跗蹠長, 露出嘴峰長) に全頭長を加えた 5 変数で, 誤判別率が約 0.055 の精度を持った判別 が可能であった (Table 8)。この場合の誤判別率は, 同一場所からの採集によるもの（標本 A) よりも高かったが，その原因は，異なった採集地の標本が加えられたことのほかに，長期間， 冷凍保存されていたことによる測定部位の変形（特に，全長の短縮）によるものと考えられる。

しかし, 誤判別率 0.055 は, 例えば野外で採集した個体の計測值から雌雄を判定して, 個体 群の性比を知万うとする目的の場合などでは, 許容できる範囲であろう。したがって, 野外で 捕獲時に得た計測值を(2) 式あるいは (3) 式に適用することで, 誤判別率 5\% 以内の精度で, 雌雄判別を行うことができる。

ただし，分析に用いた標本の計測値を得られた判別式に当てはめて雌雄を判別したときの誤 判別率は, 同一場所からの採集標本の場合も, 各地からの標本の場合 (Table 8) も, いずれも 雌では低く，雄では高かった。これは，分析に用いた標本の性比が雌に極端にかたよっていた ことの反映であると考えられる(奥野ら 1971)。(標本の性比が雌にかたよっていたのは，有害鳥 獣駆除による採集標本が常に雌の方が多かったためであるが，その原因は今の所不明である。） 判別の精度をさらに高めるためには，雄の標本を増やして分析し直すことが必要であろう。ま たここでは計測值 (それもすべて長さという 1 次元の測值) だけを用いたが，村田 (1986) が 示唆しているように，羽色なども雌雄判別のための变数として有効であるかも知れない。その 場合は，羽色を数量化する必要が生じるが，それらも含めて，今後検討する必要があろう。

ここで得られた判別関数は, 乾燥標本には適用できないことが示された。これは標本 $\mathrm{A} \sim \mathrm{C}$ がヒヨドリの非繁殖期に採集されたものであり, 繁殖期の標本を含んでいる標本 D は同様に 扱えないことによる。さらに, 变数の平均値を比較した結果では, 標本 D は標本 A〜C に比 べて雌の自然翼長が有意に大きかった (Table 1 and 3)。また，標本 D の分散は，採集地に関 係なく標本 $\mathrm{A} \sim \mathrm{C}$ よりも常に高かった。この原因としては，標本が固化しているため，翼長や 尾長などの測定がしにくく，測定精度が落ちたこと，標本によっては翼端や尾端が摩耗してい るため, 計測值が小さくなりやすかったことなどが考えられる。今後, 繁殖期に採集した標本 を集め判別式を求め, 地域固体群体の比較を行っていきたいと考えている。いずれにしても, 乾燥標本の雌雄判別は, 別途検討する必要があろう。 
摘要

ヒヨドリの雌雄を判別する方法を確立するために，外部形態部位の計測值を基に，判別分析 を行った。分析には, 神奈川県三浦半島および東京周辺で捕獲されたもので, 捕獲直後に計測 したもの（標本 $\mathrm{A}, \mathrm{C}$ ), 関東〜関西の各地で採集された後，冷凍保存されていたもの（標本 B), 北海道〜九州の各地で採集され，山階鳥研標本室に保存されていたもの（標本 D) を用いた。

1. 標本 $\mathrm{A} \sim \mathrm{C}$ では, 測定した 10 部位の大きさと体重の平均值は, ほとんどの場合で, 雄 の方が雌よりも有意に大きく，体のサイズにおける明瞭な性的二型を示した。

2. 各計測值の標本ごとの平均值と分散を標本間で比較した結果, 捕獲後冷凍保存されてい た標本 B の一部の部位を除くと，標本 A〜C は同じ母集団からの抽出標本と考えられた。そ れに対して, 乾燥標本 (標本 D) はこれらとは異なった母集団からのものと結論された。

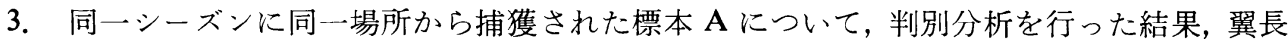
のみを用いた場合には，誤判別率は 0.08 であったが，変数の数を増やしていくと，䜋判別率は 低下した。しかし, 跗蹠長, 鼻孔前端長, 全長, 翼開長, 全頭長, 嘴幅の 6 変数を用いたとき は, 測定した全変数 (11 変数)を用いた場合とほぼ同程度の判別効率 (誤判別率 0.021) を示し た。

4. より一般的な判別関数を得るために，各地で得られた標本も加えて判別分析を行った結 果, 尾長, 跗蹠長, 鼻孔前端長, 翼開長, 全頭長の 5 変数を用いることで, 誤判別率 0.043 の 判別関数が得られた。また, この代替として, 自然翼長, 尾長, 跗蹠長, 嘴峰長, 全頭長の 5 変 数を用いた場合には, 誤判別率は 0.055 であった。したがって，これらの関数を用いて，野外 で捕獲したヒョドリの雌雄を判別できる。

5. 標本 $\mathrm{A} \sim \mathrm{C}$ で得られた判別関数を乾燥標本 (標本 D) に適用したところ, 誤判別率は 0.26 であった。このため, 乾燥標本の雌雄判別は, 別途検討する必要がある。

\section{引用文 献}

Bortolotti, G. R. 1984. Sexual size dimorphism and age-related size variation in bald eagles. J. Wildl. Manage. 48: 72-81.

Garcelton, D. K., Martell, M. S., Redig, P. T. and Buoen, L. C. 1985. Morphometric, karyotiypic, and laparoscopic techniques for determining sex in bald eagles. J. Wildl. Manage. 49: 595-599. James, F. C., Engstrom, R. T., Nesmith, C. and Layboune, R. 1984. Inferences about population movements of Red-Winged Blackbirds from morphological data. Am. Midl. Nat. 111: 319-331.

清棲幸保 1978. 日本鳥類大戝鑑. I. (增補改訂版), 講談社.

Miller, S. L., Gregg, M. A., Kuritsubo, A. R., Combs, S. M., Murdock, M. K., Nilsson, J. A., Noon, B. R. and Botzler, R. G. 1988. Morphometric variation in tundra swans: relationships among sex and age classes. Condor 90: 802-815.

村田浩一・鈴木 忠・安福 守・吉竹 渡 1988. 判別分析によるタンチョウの雌雄鑑別. 山階鳥研報 20: 101-106.

村田省吾 1986. 翼長によるとヨドリの雌雄の判別. 日本鳥類標識協会誌 1: 27-29.

中村和雄・松咸 茂・宮下 直 1984. 冬期の農耕地 (筑波)に抢けるヒヨドリ個体群の動き(講要). 鳥 33: 93.

奥野忠一・父米 均・芳賀敏郎・吉沢 正 1971. 多变量解析法, 日科技連.

Pepin, D. 1985. Morphological characteristics and sex classification of red-legged partridge. J. Wildl. Manage. 49: 228-237.

Piersma, T. 1988. Morphological variation in European population of Great Crested Grebes Podiceps cristatus in relation to age, sex and season. J. Orn. 129: 299-316. 
山階芳麿 1933. 日本の鳥類と其の生態, 第一巻, 梓書房.

吉井 正 1979. わたり鳥. 東海大学出版会.

中村和雄：農業研究センター鳥害研究室. 干305 茨城県つくば市観音台 3-1-1

佐藤文男・杉森文夫 -今村知子：山階鳥類研究所. $\overline{7} 270-11$ 千葉県我孫子市高野山 